\title{
Kemudahan Penggunaan dan Harga Terhadap Minat Beli Online Konsumen
}

\author{
Hapsawati Taan* \\ Jurusan Manajemen, Fakultas Ekonomi, Universitas Negeri Gorontalo \\ Gorontalo, Indonesia \\ Email: hapsataan@yahoo.co.id
}

\begin{abstract}
Abstrak
Tujuan penelitian ini adalah untuk mengetahui pengaruh kemudahan penggunaan dan harga terhadap minat beli konsumen pada situs belanja online Shopee. Pendekatan jenis kuantitatif deskriptif. Populasi yang digunakan adalah orang yang pernah melakukan pembelian online pada toko online Shopee. Populasi infinity, jumlah sampel yang digunakan sebanyak 83 responden. Unit analisis adalah Mahasiswa Fakultas Ekonomi Universitas Negeri Gorontalo. Penarikan sampel metode non probability sampling dengan cara accidental sampling. Hasil penelitian menunjukkan bahwa kemudahan penggunaan berpengaruh positif dan signifikan terhadap minat beli online konsumen. Harga berpengaruh positif dan signifikan terhadap minat beli.Kemudahan penggunaan dan harga berpengaruh secara simultan terhadap minat beli. Pengaruh yang paling dominan adalah variabel harga. Hasil ini berimplikasi bagi para peneliti lain untuk melakukan penelitian dengan cakupan lebih luas dengan subtansi yang sama untuk membantu mengkaji kemudahan penggunaan dan harga dalam sistem belanja online Shopee. Implikasi lain yaitu bagi pimpinan manajemen toko online Shopee atau pengambil kebijakan di online Shopee hendaknya mempertimbagan lebih lanjut mengenai kebijakan-kebijakan yang dapat meningkatkan minat beli online Shopee.
\end{abstract}

Kata kunci: Harga, Kemudahan Penggunaan, Minat Beli, Shopee

\begin{abstract}
The purpose of this study was to determine the effect of ease of use and price on consumer buying interest on the Shopee online shopping site. escriptive quantitative type approach. The population used is people who have made online purchases at the Shopee online store. Population infinity, the number of samples used was 83 respondents. The unit of analysis is students of the Faculty of Economics, State University of Gorontalo. Non-probability sampling method with accidental sampling method. The results showed that ease of use had a positive and significant effect on consumer buying interest online. Price has a positive and significant effect on purchase intention. Ease of use and price simultaneously influence purchase intention. The most dominant influence is the price variable. Another implication is that Shopee online store management leaders or Shopee online policy makers should consider further about policies that can increase Shopee's online buying interest.
\end{abstract}

Keywords: Ease of Use, Price, Purchase Interest, Shopee

\section{Pendahuluan}

Keberhasilan sistem perdagangan online di Indonesia tidak lepas dari dukungan masyarakat Indonesia yang mendambakan sebuah kepraktisan dalam berbelanja. Shopee merupakan suatu perusahaan e-commerce yang menerapkan bentuk customer to customer (C2C). Persaingan bisnis e-commerce menuntut penjual harus mampu bersikap dan bertindak cepat dan tepat dalam menghadapi persaingan dilingkungan bisnis yang bergerak sangat dinamis. Oleh karena itu, Shopee Indonesia menyediakan beragam jenis produk yang ditawarkan. Keberagaman produk yang ditawarkan Shopee Indonesia memiliki beberapa kategori meliputi fashion, gadget, alat kosmetik, alat elektronik, hobi dan koleksi, fotografi, perlengkapan olahraga, otomotif, vitamin dan suplemen, perlengkapan rumah, makanan dan minuman, souvenir, hingga voucher belanja.

Minat merupakan kecenderungan untuk dapat tertarik atau terdorong untuk memperhatikan seseorang, sesuatu barang

\footnotetext{
* Corresponding Author

atau kegiatan dalam bidang-bidang tertentu. Durianto dan Liana (2004) minat beli merupakan sesuatu yang berhubungan dengan rencana konsumen untuk membeli produk tertentu serta berapa banyak unit yang dibutuhkan pada periode tertentu. Menurut Dullah (2001) minat merupakan perilaku yang muncul sebagai respon terhadap suatu objek yang menunjukkan keinginan pelanggan untuk melakukan pembelian. Karena minat terhadap sesuatu yang diinginkan, maka muncul keinginan untuk membeli. Saat ini berbelanja di Shopee sedang trend di berbagai kalangan, dari anak muda, mahasiswa hingga orangtua pun gemar untuk berbelanja di Shopee. Tak heran banyak sekali penjual yang menjual dagangannya di Shopee dengan segala kemudahan-kemudahan yang ditawarkan untuk menarik minat para calon membeli.

Penelitian terdahulu (Munandar \& Chadafi, 2016; Khairul Alam, 2017) hasil penelitian menujukkan bahwa variabel harga merupakan variabel yang paling dominan berpengaruh terhadap keputusan pembelian online. Sedangkan hasil penelitian yang berbeda dilakukan oleh Prabudi (2014) hasil penelitian menunjukan bahwa harga 
berpengaruh negatif terhadap keputusan pembelian. Ayuningrum \& Idris (2016) dan Ma'ruf (2018) hasil penelitian menunjukkan bahwa kemudahan penggunanan, pengalaman masa lalu, kepercayaan konsumen dan persepsi harga memiliki pengaruh positif dan signifikan terhadap minat beli. Sedangkan hasil penelitian berbeda yang dilakukan oleh Lestari (2018) yang menyatakan bahwa variabel persepsi kemudahan penggunaan tidak berpengaruh terhadap minat menggunakan software zahir. Beberapa penelitian terdahulu memunculkan adanya kesenjangan (gap) terhadap variabel yang berpengaruh terhadap minat beli online konsumen, sehingga peneliti tertarik untuk meneliti lebih lanjut mengenai variabel yang berpengaruh terhadap minat beli online. Penelitian terdahulu menggunakan menggunakan beberapa variabel sedangkan pada penelitian ini hanya menggunakan dua variabel yakni kemudahan penggunaan dan harga.

Kemudahan penggunaan didefinisikan sebagaimana seseorang percaya bahwa menggunakan suatu teknologi akan bebas dari usaha. Pengguna atau sesorang yang menganggap suatu sistem informasi mudah digunakan maka pastilah akan digunakan sistem tersebut, sebaliknya jika suatu sistem informasi dirasa sulit digunakan maka pastilah tidak akan digunakan suatu sistem informasi tersebut. Nasution (2004) menyatakan bahwa teknologi informasi yang lebih fleksibel, mudah dipahami dan mudah mengoperasikannya sebagai karakteristik kemudahan penggunaan. Keyakinan akan kemudahan penggunaan suatu teknologi dapat dismpulkan bahwa dalam mengoperasikannya tidak banyak memerlukan suatu usaha

Menurut Davis (1989) menyebutkan indikator yang digunakan untuk mengukur kemudahan penggunaan yaitu mudah dipelajari, jelas dan mudah dimengerti, fleksibel, dan mudah dikontrol. Seseorang atau pengguna yang menolak atau tidak menggunakan suatu sistem biasanya tergantung pada suatu ketertarikan sistem tersebut. Seseorang yang merasa sistem tersebut akan memudahkan pekerjaan pastilah akan menggunakan sistem tersebut. Kemudahan dalam menggunakan sistem berarti bahwa sistem tersebut menarik atau tidak membingungkan, jelas dan mudah dimengerti.

Faktor-faktor yang mempengaruhi minat beli konsumen Kotler dan Keller (2018) diantaranya adalah harga. Buchari (2014) mengemukakan bahwa harga (price) adalah nilai suatu barang yang dinyatakan dengan uang. Menurut Dharmesta (2010) mengartikan bahwa harga merupakan sejumlah uang (ditambah beberapa barang kalau mungkin) yang dibutuhkan untuk menambahkan sejumlah kombinasi dari barang beserta pelayannya. Menurut Tjiptono (2008) menyebutkan bahwa harga merupakan satu-satunya unsur bauran pemasaran yang memberikan pemasukan atau pendapatan bagi perusahaan.

Indikator yang mencirikan harga menurut Kotler dan Amstrong (2009), yaitu: keterjangkauan harga, kesesuaian harga dengan kualitas produk, harga sesuai kemampuan atau daya saing harga, kesesuaian harga dengan manfaat. Abdullah dan Francis (2014) Penetapan harga merupakan suatu masalah ketika perusahaan harus menentukan harga untuk pertama kali. Perusahaan dapat mengejar empat tujuan utama melalui: Memaksimalkan keuntungan (profit maximization), memaksimalkan pendapatan, memaksimalkan pangsa pasar (maximum market share), kepemimpinan mutu

Tujuan pemasaran adalah memenuhi dan melayani kebutuhan serta keinginan konsumen. Konsumen dalam hal ini adalah seseorang yang menggunakan barang atau jasa. Memahami perilaku konsumen sangat penting bagi manajemen pemasaran atau mereka yang berkecimpung dalam bidang pemasaran. Dharmesta \& Handoko (2000) berpendapat bahwa perilaku konsumen adalah kegiatankegiatan individu yang secara langsung terlibat dalam mendapatkan dan mempergunakan barang-barang dan jasa termasuk didalamnya proses pengambilan keputusan pada persiapan dan penentuan kegiatan-kegiatan tersebut.

Menurut Simamora (2002) minat adalah sesuatu yang pribadi dan berhubungan dengan sikap individu yang berminat terhadap suatu obyek akan mempunyai kekuatan atau dorongan untuk melakukan serangkaian tingkah laku untuk mendekati atau mendapatkan objek tersebut. Minat beli timbul setelah adanya proses evaluasi alternatif , dan didalam proses evaluasi seseorang kan membuat suatu rangkaian pilihan mengenai produk yang hendak dibeli atas dasar merek ataupun minat. Abdullah (2003) Minat beli merupakan komponen perilaku konsumen dalam mengkonsumsi, kecenderungan responden untuk bertindak sebelum keputusan membeli benar-benar dilaksanakan.

Minat beli merupakan instruksi diri konsumen untuk melakukan pembelian atas suatu produk, melakukan perencanaan, mengambil tindakan-tindakan yang relevan seperti mengusulkan, merekomendasikan, memilih, dan akhirnya mengambil keputusan untuk melakukan peembelian. Assael (2001) Minat beli merupakan kecenderungan konsumen untuk membeli suatu merek atau mengambil tindakan yang berhubungan dengan pembelian yang diukur dengan tingkat kemungkinan konsumen melakukan pembelian. Indikator Minat Beli Ferdinand (2006), minat beli di identifikasi melalui indikatorindikator sebagai berikut: minat transaksional, minat referensial, minat preferensial. Adapun bentuk kerangka konseptual dalam penelitian ini dapat dilihat pada gambar 1 sebagai berikut :

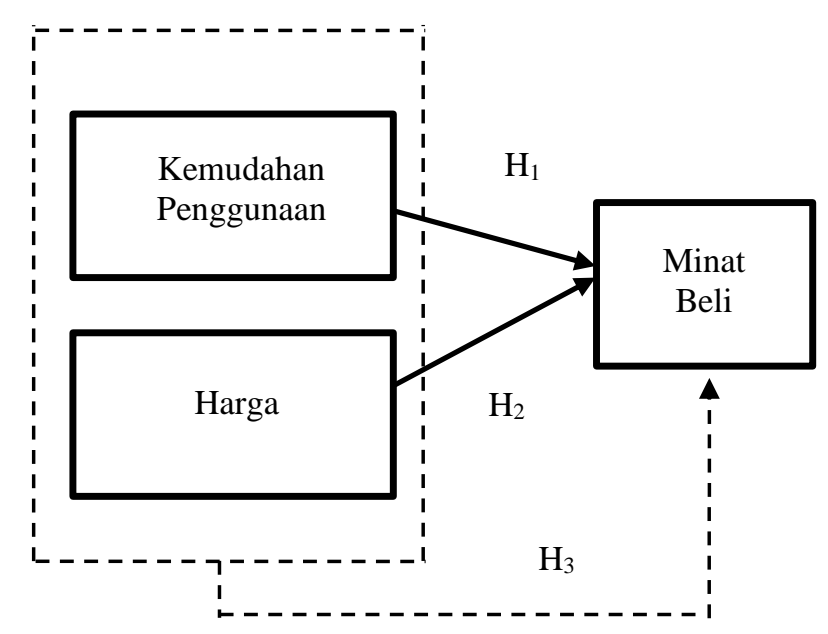

Gambar 1. Kerangka Konseptual Penelitian 
Berdasarkan permasalahan yang telah diuraikan, maka hipotesis penelitian ini adalah bahwa:

$\mathrm{H}_{1}$ : Kemudahan penggunaan berpengaruh terhadap minat beli konsumen pada situs belanja online Shopee.

$\mathrm{H}_{2}$ : Harga berpengaruh terhadap minat beli konsumen pada situs belanja online Shopee.

$\mathrm{H}_{3}$ : Kemudahan penggunaan dan harga berpengaruhsecara bersama-sama terhadap minat beli konsumen pada situs belanja online Shopee.

Tujuan penelitian ini adalah (1) Untuk mengetahui pengaruh kemudahan penggunaan terhadap minat beli konsumen pada situs belanja online Shopee. (2) Untuk mengetahui pengaruh harga terhadap minat beli konsumen pada situs belanja online Shopee (3)Untuk mengetahui pengaruh kemudahan penggunaan dan harga secara simultan terhadap minat beli konsumen pada situs belanja online Shopee.

\section{Metode}

\section{Rancangan atau Desain Penelitian}

Desain peneltian yang digunakan adalah penelitian eksplanatory, yaitu bentuk penelitian yang menjelaskan hubungan kausalitas antara variabel exogenous dan variabel endogenous. Penelitan ini menggunakan pendekatan jenis kuantitatif deskriptif, karena penelitian ini menggambarkan suatu variabel, gejala atau keadaan yang diteliti (Sugiyono, 2015), secara apa adanya dengan menggunakan data yang bersifat angka yang diperoleh dari angket atau kuesioner.

\section{Jenis dan Sumber Data}

Jenis dan sumber data yang digunakan dalam penelitian ini yaitu: (a) jenis data kualitatif yakni data yang diperoleh dalam bentuk informasi , baik secara lisan dan tulisan. (b) jenis data kuantitatif yakni data yang diperoleh dari perusahaan dalam bentuk angka-angka. Sumber data: a) Data primer, tanggapan tertulis responden terhadap sejumlah pertanyaan dan pernyataan yang diajukan dalam kuesioner penelitian.b) Data sekunder adalah sumber data penelitian yang diperoleh tidak langsung melalui media perantara (diperoleh dan dicatat oleh pihak lain) seperti data dari perusahaan, buku, arsip.

\section{Populasi dan Sampel}

Dalam penelitian ini, populasi yang digunakan adalah orang yang pernah melakukan pembelian online pada toko online Shopee. Karena populasi yang digunakan adalah seluruh yang pernah melakukan pembelian online pada toko online Shopee jumlahnya sangat banyak tersebar dan sulit diketahui secara pasti (infinity), maka dilakukan pengambilan sampel untuk penelitian ini.

Sampel adalah bagian dari jumlah dan karakteristik yang dimiliki oleh populasi (Sugiyono, 2015). Menurut Arikunto (2013), jika populasinya besar atau lebih dari 100 maka dapat diambil 10-15\% atau 20-25\% atau lebih. Untuk menentukan berapa sampel minimal yang dibutuhkan dapat dilakukan dengan menggunakan metode rumus slovin, dalam penelitian ini ditetapkan sebanyak $10 \%$. Ukuran sampel yang dapat diambil berdasarkan rumus tersebut. Jumlah sampel yang digunakan sebanyak 83 responden, yang menjadi sampel responden dalam penelitian ini adalah responden yang memiliki karakteristik tertentu, yaitu Mahasiswa Fakultas Ekonomi Universitas Negeri Gorontalo yang berusia 18-26 tahun yang pernah mengakses toko online Shopee. Objek dalam penelitian ini adalah situs toko online Shopee.

Penelitian ini menggunakan penarikan sampel metode non-probability sampling dengan cara aksidental sampling, yaitu teknik penentuan sampel berdasarkan kebetulan, siapa saja yang bertemu dengan peneliti dapat digunakan sebagai sampel, bila dipandang orang kebetulan ditemui cocok sebagai sumber data.

\section{Metode Analisis Data}

Metode analisis data dalam penelitian ini digunakan untuk mengetahui hubungan antara harga, kemudahan penggunaan, produk terhadap minat beli online. Teknik analisis data dalam penelitian ini menggunakan metode analisis regresi. Metode analisis regresi yang digunakan adalah analisis regresi linear berganda yang ditransformasikan ke logaritma berganda dengan menggunakan logaritma natural, bentuk persamaannya adalah sebagai berikut:

Dimana:

$$
Y^{\prime}=\beta_{0}+\beta_{1} X_{1}+\beta_{2} X_{2}
$$

$$
\begin{array}{ll}
Y & =\text { Minat beli } \\
\beta_{0} & =\text { Konstanta } \\
\beta_{1} \beta_{2} & =\text { Variabel yang dicari untuk mengukur elastisitas } \\
& \text { hasil terhadap variabel } \mathrm{X}_{1}, \mathrm{X}_{2}, \\
X_{1} & =\text { Kemudahan penggunaan } \\
X_{2} & =\text { Harga }
\end{array}
$$

Uji Heteroskedastisitas bertujuan untuk menguji apakah dalam model regresi terjadi ketidaksamaan varian dari residual pada model regresi. Model regresi yang baik adalah homoskedastisitas. Cara untuk mendeteksinya adalah melihat grafik plot antara nilai prediksi variabel terikat (dependen) yaitu ZPRED sebagai (X) dengan residualnya SRESID sebagai (Y). Jika ada pola tertentu, seperti titik-titik yang ada membentuk pola tertentu yang teratur (bergelombang, melebar kemudian menyempit), maka mengindikasikan telah terjadi heteroskedastisitas. Jika tidak ada pola yang jelas, serta titik-titik menyebar diatas dan dibawah angka 0 pada sumbu Y, maka tidak terjadi heteroskedastisitas. (Priyatno, 2016:131).

\section{Hasil dan Pembahasan}

\section{Hasil}

\section{Hasil Analisis Regresi Berganda}

$$
Y^{\prime}=\beta_{0}+\beta_{1} X_{1}+\beta_{2} X_{2}
$$

Berdasarkan rumus di atas dapat dijelaskan persamaan sebagai berikut:

1. Constanta sebesar $-4,406$ artinya jika harga, kemudahaan penggunaan dan kualitas produk nilainya adalah 0 , maka nilai minat beli adalah 4,406 
2. Nilai koefisien regresi variabel $\left(\mathrm{X}_{1}\right)$ kemudahaan penggunaan sebesar 0,423 memiliki arti jika nilai kemudahaan penggunaan dinaikkan sebesar 0,423 maka akan terjadi penambahan nilai minat beli akan tetapi dengan asumsi nilai variabel harga adalah tetap.

3. Koefisien regresi variabel harga $\left(\mathrm{X}_{2}\right) 0.622$ artinya jika nilai harga memiliki kenaikan hingga 0.622 maka terjadi penambahan nilai minat beli dengan asumsi nilai variabel kemudahaan penggunaan tetap.

Tabel 1. Uji Analisis Regresi Berganda

\begin{tabular}{lccccc}
\hline \multicolumn{6}{c}{ Coefficients $^{\mathrm{a}}$} \\
\cline { 1 - 3 } Model & $\begin{array}{c}\text { Unstandardiz } \\
\text { ed } \\
\text { Coefficients }\end{array}$ & $\begin{array}{l}\text { Stand. } \\
\text { Coeff. }\end{array}$ & & Sig. \\
\cline { 2 - 4 } & B & $\begin{array}{c}\text { Std. } \\
\text { Error }\end{array}$ & Beta & & \\
\hline $\begin{array}{l}\text { (Constant) } \\
\text { Kemudaha } \\
\text { anPenggun }\end{array}$ & $-4,406$ & 2,170 & & $-2,031$ &, 046 \\
$\begin{array}{l}\text { aan } \\
\text { Harga }\end{array}$ &, 623 &, 088 &, 362 & 4,818 &, 000 \\
&, 622 &, 090 &, 519 & 6,921 &, 000
\end{tabular}

a. Dependent Variable: MinatBeli

Sumber:, Data olahan SPSS 19, 2020

\section{Uji Hipotesis}

\section{a. Uji Parsial (t-hitung)}

Pengujian Hipotesis (Ha), dasar pengambilan keputusan:

1. Jika nilai Sig $<0,05$ atau $\mathrm{t}_{\text {hitung }}>\mathrm{t}$ tabel, maka terdapat pengaruh variabel $\mathrm{X}$ terhadap variabel $\mathrm{Y}$

2. Jika nilai Sig $>0,05$ atau $t_{\text {hitung }}<\mathrm{t}_{\text {tabel, }}$, maka tidak terdapat pengaruh variabel $\mathrm{X}$ terhadap variabel Y

Berdasarkan tabel 2 uji t hitung di bawah, memperoleh nilai Sig. kemudahan penggunaan $\left(\mathrm{X}_{1}\right)$ adalah sebesar $0,000<0.05$ dan $\mathrm{t}$ Hitung 4,818> t tabel 1,664 Dengan demikian hipotesis uji $\mathrm{t}$ untuk $\mathrm{H}_{\mathrm{a}}\left(, \mathrm{X}_{1}\right)$ berpengaruh. Dengan demikian hipotesis pertama $\left(\mathrm{H}_{\mathrm{a}}\right)$ dapat dibuktikan atau diterima, atau terdapat pengaruh variabel kemudahan penggunaan terhadap minat beli.

Berdasarkan tabel 2 uji t hitung di bawah, memperoleh nilai Sig. harga $\left(\mathrm{X}_{2}\right)$ adalah sebesar $0,000<0.05$ dan $\mathrm{t}_{\text {Hitung }}$ $6,921>\mathrm{t}_{\text {tabel }}$ 1,664, Dengan demikian hipotesis uji $\mathrm{t}$ untuk $\mathrm{H}_{\mathrm{a}}\left(\mathrm{X}_{2}\right)$ berpengaruh. Maka hipotesis kedua $\left(\mathrm{H}_{\mathrm{a}}\right)$ dapat dibuktikan atau diterima, variabel yang sangat berpengaruh terhadap minat beli adalah variabel harga $\left(\mathrm{X}_{2}\right)$. Maka dapat dijelaskan terdapat pengaruh variabel harga terhadap minat beli.

$\mathrm{t}_{\text {tabel }}=\mathrm{t}(\alpha / 1 ; \mathrm{n}-\mathrm{k}-1)=\mathrm{t}(0,05 ; 79)=1,664$
Tabel 2. Uji t (t-hitung)

\begin{tabular}{|c|c|c|c|c|c|}
\hline \multicolumn{6}{|c|}{ Coefficients $^{\mathrm{a}}$} \\
\hline \multirow{2}{*}{ Model } & $\begin{array}{r}\text { Unsta } \\
\text { Coef }\end{array}$ & $\begin{array}{l}\text { rdized } \\
\text { ients }\end{array}$ & $\begin{array}{l}\text { Stand. } \\
\text { Coeff. }\end{array}$ & \multirow{2}{*}{$\mathrm{t}$} & \multirow{2}{*}{ Sig. } \\
\hline & B & $\begin{array}{c}\text { Std. } \\
\text { Error }\end{array}$ & Beta & & \\
\hline (Constant) & $-4,406$ & 2,170 & & $-2,031$ &, 046 \\
\hline $\begin{array}{l}\text { Kemudaha } \\
\text { anPenggun } \\
\text { aan }\end{array}$ & ,423 & ,088 & ,362 & 4,818 & ,000 \\
\hline Harga & ,622 & ,090 &, 519 & 6,921 & ,000 \\
\hline
\end{tabular}

a. Dependent Variable: MinatBeli

Sumber: data olahan SPSS 19, 2020

b. Uji Simultan (F hitung)

Tabel 3. Uji (F-hitung)

\begin{tabular}{|c|c|c|c|c|c|}
\hline \multicolumn{6}{|c|}{ ANOVA $^{b}$} \\
\hline Model & $\begin{array}{l}\text { Sum of } \\
\text { Squares }\end{array}$ & Df & $\begin{array}{c}\text { Mean } \\
\text { Square }\end{array}$ & $\mathrm{F}$ & Sig. \\
\hline 1 Regression & 1323,579 & 3 & 441,193 & 120,997 &, $000^{\mathrm{a}}$ \\
\hline Residual & 288,059 & 79 & 3,646 & & \\
\hline Total & 1611,639 & 82 & & & \\
\hline
\end{tabular}

a. Predictors: (Constant), Kemudahaan Penggunaan, Harga

b. Dependent Variable: Minat Beli

Sumber: Data Olahan SPSS19, 2020

Dasar pengambilan keputusan:

1. Jika nilai $\operatorname{Sig}<0,05$ atau $F_{\text {hitung }}>F_{\text {tabel }}$, maka terdapat pengaruh variabel $\mathrm{X}$ secara simultan terhadap variabel Y

2. Jika nilai $\mathrm{Sig}>0,05$ atau $\mathrm{F}_{\text {hitung }}<\mathrm{F}$ tabel, maka tidak terdapat pengaruh variabel $\mathrm{X}$ secara simultan terhadap variabel $\mathrm{Y}$

$$
\mathrm{F}_{\text {tabel }}=\mathrm{F}(\mathrm{k} ; \mathrm{n}-\mathbf{1})=\mathrm{F}(1 ; 79)=3,11
$$

Berdasarkan tabel 3 hasil uji $\mathrm{F}$ penelitian ini memperoleh nilai $F_{\text {hitung }}$ sebesar 120,997 lebih besar dari $F_{\text {Tabel }}$ 3,11dan nilai signifikan $(P$ value $)$ sebesar $0,000<0,05$, maka model regresi dapat dipakai untuk menguji pengaruh variabel bebas terhadap variabel terikat. Berdasarkan tabel tersebuut dapat dijelaskan bahwa kedua variabel yaitu kemudahaan penggunaan dan harga berpengaruh secara bersama-sama terhadap variabel minat beli online.

\section{Uji Koefisien Determinasi}

Berdasarkan tabel 4 di bawah memperoleh nilai R sebesar 0,906 dan nilai $R$ square sebesar 0,821 artinya terdapat pengaruh yang kuat antara variabel kemudahan penggunaan dan harga terhadap minat beli, nilai adjudted $R$ square sebesar 0,814 atau sebesar $81,4 \%$ variabel kemudahan penggunaan dan harga memberikan kontribusi untuk mempengaruhi variabel minat beli, adapun sisanya sebesar $18,6 \%$ dipengaruhi oleh faktor-faktor yang tidak diteliti dalam penelitian ini. Tingginya nilai adjusted $R$ square dapat dijelaskan bahwa berdasarkan hasil penelitian konsumen sangat menyukai belanja online dalam hal ini 
adalah online Shopee, semua kebutuhan baik kebutuhan rumah tangga, pangan, dan kebutuhan sekunder maupun tersier dapat dibelanja melalui online Shopee ini, dan penggunaan aplikasi bisnis Shopee ini mudah untuk di pahami sehingga kosumen senang menggunakan aplikasi online Shopee.

Tabel 4. Uji Koefisien Determinasi

\begin{tabular}{lcrrr}
\hline \multicolumn{4}{c}{ Model Summary $^{\mathrm{b}}$} \\
\hline Model & $\mathrm{R}$ & R Square & $\begin{array}{c}\text { Adjusted R } \\
\text { Square }\end{array}$ & $\begin{array}{l}\text { Std. Error of } \\
\text { the Estimate }\end{array}$ \\
\hline 1 &, $906^{\mathrm{a}}$ &, 821 & $\mathbf{, 8 1 4}$ & 1,90953 \\
\hline a. Predictors: (Constant), Kemudahaan Penggunaan , & \\
Harga \\
b. Dependent Variable: Minat Beli \\
Sumber: Data Olahan SPSS 19, 2020
\end{tabular}

\section{Pembahasan}

Berada pada era industry 4.0 serta didukung perkembangan teknologi informasi dan teknologi yang semakin canggih berdampak pada perkembangan pemenuhan kebutuhan manusia. Aktivitas pemenuhan kebutuhan manusia semakin banyak berbasis online. Salah satu kegiatan bisnis berbasis online adalah online shoop Shopee, sering menawarkan banyak promo serta diskon yang pastinya digemari para pembeli, memiliki fitur terdekat yang memungkinkan pembeli mencari penjual terdekat dari posisi calon pembeli berada, adanya fitur beriklan bagi para penjual yang ingin produknya berada diurutan atas, ada pula fitur live chat yang memungkinkan penjual dan pembeli berinteraksi mengenai produk yang dijual, potensi transaksi yang cukup besar, adanya fasilitas ongkir gratis dengan ketentuan yang berlaku, tersedianya kategori produk yang luas. online Shopee juga menduduki peringkat pertama aplikasi marketplace yang sering di unduh pada platform iOS dan Android. Shopee terdiri dari ribuan penjual didalamnya.

\section{Pengaruh Kemudahan Penggunaan terhadap Minat Beli}

Berdasarkan hasil analisis pada variabel kemudahan penggunaan menunjukkan bahwa kemudahan penggunaan berpengaruh positif dan signifikan terhadap minat beli online konsumen mahasiswa Fakultas Ekonomi Universitas Negeri Gorontalo pada situs belanja online Shopee. Hal ini berarti bahwa kemudahan penggunaan merupakan hal yang penting dalam menentukan apakah suatu sistem akan berjalan lancar atau malah sebaliknya. Semakin mudah konsumen dalam mengakses setiap opsi yang ada di Shopee, akan mendorong minat beli online konsumen mahasiswa Fakultas Ekonomi Universitas Negeri Gorontalo. Sebaliknya jika opsi yang ada di Shopee di rasa sulit maka akan membuat minat beli online konsumen mahasiswa Fakultas Ekonomi Universitas Negeri Gorontalo menurun. Hasil analisis ini menerima hipotesis 1. Apakah kemudahan penggunaan berpengaruh terhadap minat beli online konsumen pada situs belanja online Shopee. Pada variabel ini nilai tertinggi pada indikator aplikasi Shopee tidak membutuhkan banyak tenaga dalam pengoperasiannya dan aplikasi Shopee dapat digunakan dimana saja dan kapan saja.

Hasil penelitian ini juga relevan dengan penelitian yang dilakukan oleh Cho (2015), yang menyatakan bahwa kemudahan penggunaan memiliki pengaruh yang signifikan terhadap minat pembelian online. Penelitian ini sejalan dengan penelitian Khotimah (2018), yang menyatakan bahwa kemudahan penggunaan berpengaruh signifikan terhadap minat beli konsumen online shop. Sejalan dengan penelitian Febriyani (2019), yang menyatakan bahwa kemudahan penggunaan secara parsial berpengaruh positif dan signifikan terhadap minat beli. Indikator kemudahan penggunaan digunakan saat berbelanja online memiliki penilaian yang besar, sehingga menjadi alat ukur variabel minat beli.

Sejalan dengan temuan Prathama (2019) penelitian yang dilakukan terhadap konsumen ecommerce Lazada, dengan hasil penelitian yang menyatakan bahwa kemudahan penggunaan berpengaruh positif dan signifikan terhadap minat beli konsumen Lazada. Sejalan dengan penelitian yang dilakukan Karnadjaja dkk. (2018), yang menyatakan bahwa kemudahan penggunaan berpengaruh terhadap minat belanja online.

Kemudahan penggunaan terhadap minat beli online konsumen, pihak manajemen online Shopee cenderung melakukan perbaikan kemudahan penggunaan melalui, mudah dipelajari, berbelanja di online Shopee mudah untuk dipelajari bagaimana cara membuat akun setelah mendonload aplikasi Shopee sampai dengan mempunyai akun sendiri agar dapat mengakses aplikasi belanja Shopee. selanjutnya jelas dan mudah dimengerti, penjualan online Shopee mempunyai kemudahan dalam berbelanja, mudah dimengerti cara atau langkah-langkah pembelian karena dapat dengan mudah dipahami pembelanjaan tersebut karena konsumen diberikan notifikasi saat melakukan pembelian seperti langkah-langkah memilih barang sudah tertera tulisan "beli" pada samping gambar dengan begitu konsumen mudah memahaminya.

Berdasarkan fakta yang ada dilapangan dapat dijelaskan bahwa kemudahan penggunakan dapat mempengaruhi minat beli online konsumen mahasiswa Fakultas Ekonomi Universitas Negeri Gorontalo, konsumen tertarik untuk membeli karena dapat memilih produk dengan hanya melihat gambar yang ada pada toko di aplikasi Shopee, langkah-langkah serta metode pembayaran juga mudah di mengerti. Kemudahan penggunaan di online Shopee juga fleksibel, pembelanjaan online Shopee juga mudah dan akses pembelanjaan cepat sampai ke tangan konsumen tanpa harus pergi untuk berbelanja, kerja sama pihak Shopee dengan jasa pengiriman dapat mempercepat proses pengantaran barang yang dibeli oleh konsumen hal ini yang menjadi pertimbangan konsumen untuk tertarik berbelanja di online Shopee. Disamping itu juga kemudahan dapat dikontrol, selanjutnya pembelanjaan dapat dikontrol mulai dari masuk pada keranjang pembelian sehingga konsumen faham bahwa barang yang dibeli sudah masuk pada keranjang belanja tinggal lanjutkan saja langkah-langkah selanjutnya sampai dengan metode pembayarannya, hal ini dapat menarik konsumen dalam melakukan pembelian online khususnya pada online Shopee. 


\section{Pengaruh Harga terhadap Minat Beli}

Berdasarkan hasil penelitian bahwa variabel harga pada Shopee berpengaruh positif dan signifikan terhadap minat beli online konsumen pada situs belanja online Shopee. Hal ini berarti bahwa harga merupakan salah satu faktor yang berperan penting dalam menentukan sikap konsumen dalam hal ini mahasiswa Fakultas Ekonomi Universitas Negeri Gorontalo dalam menentukan minat pembelian pada situs belanja online Shopee. Semakin murah harga yang diberikan, akan mendorong semakin tingginya minat beli online konsumen mahasiswa Fakultas Ekonomi Universitas Negeri Gorontalo untuk berbelanja di Shopee. Akan tetapi harga murah yang dimaksud adalah berkualitas baik. Sebaliknya jika harga yang ditawarkan mahal, maka minat beli online konsumen mahasiswa Fakultas Ekonomi Universitas Negeri Gorontalo akan menurun. Hasil analisis ini menerima hipotesis 2. Apakah harga berpengaruh terhadap minat beli konsumen pada situs belanja online Shopee. Pada penelitian ini harga menjadi pengaruh utama untuk minat beli online konsumen. Indikator harga tertinggi yaitu harga produk yang dijual di Shopee sesuai dengan yang diinginkan konsumen.

Hasil temuan ini sejalan dengan hasil penelitian yang dilakukan Monica (2018), yang menemukan hasil bahwa variabel harga secara parsial berpengaruh poistif dan signifikan terhadap minat beli perumahan taman safira bondowoso. Sejalan dengan peenelitian yang dilakukan Herdioko (2018), yang menyatakan bahwa harga memiliki pengaruh yang kuat terhadap minat beli.Penelitian ini didukung dengan penelitian sebelumnya oleh Verina (2014),hasil penelitian menunjukkan bahwa harga memiliki pengaruh yang positif terhadap minat beli. Hasil penelitian ini juga di dukung oleh penelitian yang dilakukan oleh Limpo dkk. (2018), yang menyatakan bahwa harga berpengaruh secara positif dan signifikan terhadap keputusan pembelian.Sejalan dengan penelitian yang dilakukan oleh Hidayah \& Rachmi (2019), yang menyatakan bahwa harga berpengaruh positif dan signifikan terhadap minat beli.

Aspek harga pihak manajemen toko online Shopee cenderung melakukan perbaikan melalui, keterjangkauan harga, harga-harga yang ditawarkan oleh penjualan online Shopee ini cukup dijangkau oleh konsumen yang melakukan pembelian di online Shopee, harga yang ditawarkan dari harga yang terendah sampai dengan tertinggi sesuai dengan produk yang dijual, keterjangkauan harga ini dapat meningkatkan minat beli konsumen pada online Shopee. Selain itu juga memperhatikan kesesuaian harga dengan kualitas produk, penjualan online Shopee menjual berbagai macam produk dengan harga yang sesuai dengan kualitas produknya, harga yang tinggi sudah tentu memiliki kualitas produk yang unggul dan berkualitas sedangkan harga yang rendah memiliki kualitas produk yang standar akan tetapi kebanyakan konsumen juga tertarik untuk membeli dengan harga yang murah karena memiliki keunikan pada produk itu sendiri baik dari bentuk serta model dari produk itu sendiri.

Harga sesuai dengan kemampuan dan daya saing harga, konsumen dalam membeli harga pasti membandingkan harga-harga dengan produknya, pada penjualan online Shopee ini memiliki produk yang sama akan tetapi harga yang dijual berbeda, dengan begitu konsumen menggunakan persepsinya dalam membeli dan menentukan harga murah atau mahal yang akan dibeli. Selanjutnya kesesuaian harga dengan manfaat, konsumen dalam membeli suatu barang pada online Shopee lebih melihat apakah harga yang ditawarkan seimbang dengan manfaat dai suatu produk yang akan dibeli, pada hasil penelitian menemukan bahwa sebagian besar konsumen lebih melihat harga yang sebanding dengan uang yang akan dikeluarkan untuk suatu produk yang akan dibeli. Hal ini menjadi keputusan konsumen untuk membeli suatu produk.

Berdasarkan fakta yang ada dapat dijelaskan bahwa harga sangat berpengaruh terhadap minat beli online konsumen mahasiswa Fakultas Ekonomi Universitas Negeri Gorontalo, konsumen yang membeli akan mempertimbangkan harga yang ditawarkan seperti harga yang murah tetapi memiliki produk yang unik dan kualitas produk yang bagus, seseorang lebih tertarik dengan hargaharga yang ditawarkan oleh online Shopee ini sehingga memiliki minat untuk membeli barang yang ditawarkan dari berbagai toko yang ada di dalam aplikasi Shopee. Akan tetapi sesekali terdapat barang yang tidak sesuai dengan harganya, contoh kasus ini seperti sepatu yang mahal harganya dan gambar produk yang dapat menarik perhatian konsumen ternyata barang tersebut tidak sesuai dengan kualitas yang dibeli sehingga dapat mempengaruhi minat beli dikemudian hari.

\section{Pengaruh Kemudahan Penggunaan dan harga terhadap Minat Beli}

Berdasarkan hasil analisis penelitian bahwa kemudahaan penggunaan dan harga berpengaruh secara simultan terhadap variabel minat beli. Dengan demikian hipotesis 3 apakah kemudahan penggunaan dan harga berpengaruh terhadap minat beli konsumen pada situs belanja online Shopee dapat diterima. Dari kedua variabel yang sangat berpengaruh terhadap minat beli adalah variabel harga $\left(\mathrm{X}_{2}\right)$. Harga yang sesuai dengan kualitas produk yang dijual serta dengan adanya kemudahan penggunaan dalam melakukan pembelanjaan di aplikasi online Shopee ini dapat mempengaruhi minat beli konsumen.

Hasil penelitian ini didukung oleh penelitian yang dilakukan Zuelseptia, dkk (2018), yang menyatakan bahwa kemudahan penggunaan memiliki efek positif dan signifikan terhadap sikap konsumen dalam pembelian online. Ma'ruf (2018) menunjukkan bahwa terdapat pengaruh posistif kemudahan penggunaan terhadap sikap konsumen dalam belanja online. Nasution (2004) menyatakan bahwa teknologi informasi yang lebih fleksibel, mudah dipahami dan mudah mengoperasikannya sebagai karakteristik kemudahan penggunaan. Keyakinan akan kemudahan penggunaan suatu teknologi dapat dismpulkan bahwa dalam mengoperasikannya tidak banyak memerlukan suatu usaha. Menurut Kotler dan Keller (2018), harga adalah satu elemen bauran pemasaran yang menghasilkan pendapatan, elemen lain menghasilkan biaya. Harga merupakan suatu nilai yang dinyatakan dalam rupiah atau sejumlah pengorbanan berupa uang yang digunakan untuk mendapatkan suatu barang. 


\section{Implikasi Penelitian}

Implikasi dalam penelitian ini bahwa kemudahan penggunaan merupakan variabel yang berpengaruh signifikan terhadap minat beli. Hasil ini berimplikasi bagi para peneliti lain untuk melakukan penelitian dengan cakupan lebih luas dengan subtansi yang sama untuk membantu mengkaji kemudahan penggunaan dalam sistem belanja online Shopee, sehingga diperoleh gambaran yang lebih luas tentang peranan kemudahan penggunaan terhadap minat beli konsumen. Selanjutnya implikasi lain yaitu bagi pimpinan manajemen toko online Shopee atau pengambil kebijakan di online Shopee hendaknya mempertimbagan lebih lanjut mengenai kebijakankebijakan yang dapat meningkatkan minat beli online Shopee.

Hasil analisis dalam penelitian ini variabel harga memiliki pengaruh positif dan signifikan terhadap minat beli online konsumen. Hasil penelitian ini berimplikasi pada perlunya para peneliti yang akan datang melakukan penelitian lanjutan mengenai subtansi aspek harga dengan cakupan yang lebih luas untuk memperoleh gambaran yang lebih komprehensif tentang harga di luar online Shopee terhadap minat beli online. Hasil penelitian ini juga berimplikasi kepada pimpinan manajemen toko online Shopee atau pengambil keputusan di toko online Shopee agar memperhatikan aspek-aspek yang mempengaruhi harga sehingga mampu membuat keputusan penetapan harga untuk meningkatkan minat beli online konsumen.

\section{Simpulan}

Kemudahan penggunaan berpengaruh positif dan signifikan terhadap minat beli online konsumen pada situs belanja toko online Shopee pada mahasiswa Fakultas Ekonomi Universitas Negeri Gorontalo, yang berarti bahwa jika suatu sistem mudah untuk digunakan, maka sistem tersebut dapat meningkatkan minat beli online konsumen. Hal ini menujukkan bahwa kemudahan penggunaan memberikan pengaruh yang signifikan terhadap minat beli online konsumen. Kemudahan penggunaan yaitu aplikasi Shopee mudah dipelajari, tidak membutuhkan banyak tenaga dalam pengoperasiannya, fleksibel, dan aplikasi Shopee dapat digunakan dimana saja dan kapan saja.

Harga berpengaruh positif dan signifikan terhadap minat beli online konsumen pada situs belanja online Shopee pada mahasiswa Fakultas Ekonomi Universitas Negeri Gorontalo, yang berarti bahwa jika harga produk yang ditawarkan murah, maka akan meningkatkan minat beli online konsumen. Hal ini menunjukkan bahwa pemberian harga yang baik dapat memberikan pengaruh yang signifikan pada situs belanja online Shopee melalui keterjangkauan harga, kesesuaian harga dengan kualitas produk, daya saing harga, dan kesesuaian harga dengan manfaat, sehingga dapat meningkatkan minat beli konsumen pada situs belanja online Shopee. Harga produk yang dijual di Shopee sesuai dengan yang diinginkan konsumen merupakan hal yang paling dominan berpengaruh terhadap minat beli konsumen pada situs belanja online Shopee.
Kemudahan penggunaan dan harga berpengaruh secara simultan terhadap minat beli online konsumen pada situs belanja online Shopee. Harga adalah variabel yang sangat berpengaruh dominan terhadap minat beli online konsumen pada situs belanja online Shopee pada mahasiswa Fakultas Ekonomi Universitas Negeri Gorontalo. Hal ini dipengaruhi salah faktor bahwa banyak konsumen yang selalu mencari harga yang murah pada situs belanja online Shopee.

\section{Referensi}

Abdullah, Thamrin. 2003. Manajemen Pemasaran. PT. Gramedia Pustaka: Jakarta

Abdullah, Thamrin dan Francis, Tantri. 2014. Manajemen Pemasaran.PT. Raja Grafindo Persada: Depok.

Arikunto, Suharsimi. 2013. Prosedur Penelitian Suatu Pendekatan Praktik. Edisi Revisi VI. PT. Rineka Cipta: Jakarta.

Assael, Henry. 2001. Consumer Behavior and Marketing Action.Thomson \& Learning: Boston.

Ayuningrum, Shinta\& Idris. 2016. Pengaruh Kemudahan Penggunaan, Pengalaman Sebelumnya, Kepercayaan Konsumen dan Persepsi Harga Terhadap Minat Beli dalam Transaksi Belanja Online. Journal of management, (online) 5(2), 110.

(https://ejournal3.undip.ac.id/index.php/djom/articl e/view/13959/ diakses 1 maret 2020)

Buchari, Alma. 2014. Manajemen Pemasaran dan Pemasaran Jasa. Alfabeta: Bandung.

Cho, Yoon. (2015). Exploring Factors That Affect Usefulness, Ease Of Use, Trust, And Purchase Intention In The Online Environment. International Journal of Management \& Information Sistems, (online) 19 No.1, 21-36. https://clutejournals.com/index.php/IJMIS/article/v iew (diakses 1 maret 2020)

Davis, Fred. 1989. "Perceived Usefulness, Perceived Ease Of Use, and User Acceptance of Information Technology". MIS Quarterly.

Dharmesta, Basu Swastha dan Handoko, T. Hani. 2000. Analisa Perilaku Konsumen. Edisi Pertama Cetakan Ketiga. Yogyakarta: BPFE UGM.

Dharmesta, Basu Swastha. 2010. Manajemen Penjualan: Pelaksanaan Penjualan. BPFE-: Yogyakarta.

Dullah, Yamit. 2001. Manajemen Kualitas Produk Dan Jasa. Ekonisia: Yogyakarta.

Durianto, \& Liana. 2004. Strategi Menaklukan Pasar; Melalui Riset Ekuitas dan Perilaku Merek.PT. Gramedia Pustaka Utama: Jakarta

Febriyani, Dyah Anggita. 2019. Pengaruh Persepsi Kemudahan Penggunaan dan Persepsi Kemanfaatan Terhadap Minat Beli Online Pada Mahasiswa UST Yogyakarta Pengguna Zalora. Jurnal Ekobis Dewantara (Online) 1.11 (2019): 1019.

(http://jurnalfe.ustjogja.ac.id/index.php/ekobis/arti cle/view/873/ diakses 20 maret 2020) 
Ferdinand, Augusty. 2006. Pengembangan Minat Beli Merek Ekstensi.Badan Penerbit Universitas Diponegoro: Semarang.

Hartono, Jogiyanto. 2007. Model Kesuksesan Sistem Teknologi Informasi. ANDI: Yogyakarta.

Herdioko, Jonathan. 2018. Pengaruh Produk dan Harga Terhadap Minat Beli Konsumen Dalam Berbelanja Produk Kopi Secara Daring: Studi Kasus pada Situs Internet Otten Coffee, Jurnal Riset Manajemen dan Bisnis (Online) 12.2 (2018): 129-136.

(http://e-

journalfb.ukdw.ac.id/index.php/jrmb/article/ diakses 22 maret 2020)

Hidayah, Nurul., dan Asminah, Rachmi. 2019. Pengaruh Harga Dan Lokasi Terhadap Minat Beli Konsumen Di Ayam Goreng Nelongso Malang." Jurnal Aplikasi Bisnis (Online) 5.1 (2019): 149-152. (http://jab.polinema.ac.id/index.php/jab/article/vi ew/310/

diakses 22 maret 2020)

Karnadjaja, Claudia Cindy, Diyah Tulipa, dan Robertus Sigit Haribowo Lukito. 2018. Pengaruh persepsi risiko, manfaat, dan kemudahan penggunaan terhadap minat belanja online melalui kepercayaan dan sikap pada konsumen Zalora di Surabaya, Jurnal Kajian Ilmiah Mahasiswa Manajemen (Online) $\quad 6.2 \quad$ (2018): 116-130. (http://journal.wima.ac.id/index.php/KAMMA/arti cle/ diakses 21 maret 2020)

Kotler, Philip \& Amstrong, Gary. 2014. Prinsip-prinsip Manajemen. Edisi 14. Jilid 1. Erlangga: Jakarta.

Kotler, Philip \& Keller, Kevin Lane. (2018). Manajemen Pemasaran. Jilid I.

Khairul Amal, Hafasnuddin. 2017. Pengaruh Harga Dan Kepercayaan Terhadap Niat Pembelian Online Dengan Persepsi Nilai Sebagai Variabel Mediasi (Studi Pada Konsumen Blibli.Com Di Kota Banda Aceh). Jurnal Ilmiah Mahasiswa Ekonomi Manajemen, (online) 2(1), 252-266. (https://etd.unsyiah.ac.id/index.php?p=show detail

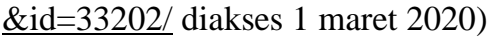

Khotimah, Khusnul. 2018. Pengaruh Kemudahan Penggunaan, Kepercayaan Konsumen Dan Kreativitas Iklan Terhadap Minat Beli Konsumen Online-Shop, Jurnal Manajemen Strategi dan Aplikasi Bisnis (Online) 1.1 (2018): 19-26.

Lestari, Elis. 2018. Pengaruh Persepsi Kemudahan Penggunaan, Persepsi Kebermanfaatan, Computer Self Efficacy, Facilitating Cinditions Dan Pengetahuan Akuntansi Terhadap Minat Menggunakan Software Zahir. Skripsi: Surakarta.

Limpo, Lita., Rahim, Abdul., dan Hamzah. 2018. Effect of Product Quality, Price, and Promotion to Purchase Decision. International Journal on Advanced Science, Education, and Religion, (online) 1(1), 922. (https://doi.org/10.33648/ijoaser.v1i1.2/ diakses 1 maret 2020)

Ma'ruf, Sabili. 2018. The Influence Of Ease Of Use, Usefulness, Perceived Risk, And Convenience On Consumer Attitude On Online Shopping (A Case Study Of Lazada.Com) Oleh. Jurnal Fakultas
Ekonomi, (online) 3, 535-549. (http://journal.student.uny.ac.id/ojs/index.php/jmbi /article/view//diakses 1 maret 2020)

Munandar, dan Chadafi. 2016. Pengaruh Harga, Celebrity Endorser, Kepercayaan, dan Psikologi terhadap Keputusan Pembelian Online Shop Di Media Sosial Instagram. Visioner \& Strategis ISSN : 2338-2864, (online) 5(2), 1-8. (www.journal.unimal.ac.id/visi/article/view/215/ diakses 1 maret 2020)

Monica, Elina. 2018. Pengaruh Harga, Lokasi, Kualitas Bangunan dan Promosi Terhadap Minat Beli Perumahan Taman Safira Bondowoso. International Journal of Social Science and Business (Online) 2.3 (2018): 141-149. (https://ejournal.undiksha.ac.id/index.php/IJSSB/ar ticle/view/diakses 21 maret 2020)

Nasution, M. Nur. 2004. Manajemen Jasa Terpadu. Bogor, PT. Ghalia Indonesia.

Prabudi, Cecep. 2014. Analisis Pengaruh Kualitas Produk Harga Dan Citra Merek Terhadap Keputusan Pembelian Produk Bakpia Wilis Di Kota Magelang, Semarang Dan Jogjakarta. Skripsi

Priyatno, Duwi. 2016. Belajar Alat Analisis Data Dan Cara Pengolahannya Dengan SPSS. Yogyakarta. Penerbit Gava Media

Prathama, Frenky. 2019. Pengaruh Kemudahan Penggunaan Aplikasi dan Kepercayaan

Konsumen terhadap Minat Beli Ulang Konsumen E- commerce Lazada." Jurnal Agora

(Online)

7.1

http://publication.petra.ac.id/index.php/manajemen -bisnis/ diakses 20 maret 2020)

Sugiyono. 2015. Metode Penelitian Pendidikan Pendekatan Kuantiatif, Kualitatif dan $R \& D$ Bandung, Alfabeta

Simamora, Bilson. 2002. Panduan Riset Perilaku Konsumen.PT. Gramedia Pustaka Utama: Jakarta

Tjiptono, Fandy. 2014. Pemasaran Jasa: Prinsip, Penerapan, dan Penelitian. Alfabeta: Bandung.

Verina, Eunike., Yulianto, Edi., dan Latief, Wasis. 2014. Faktor-Faktor Yang Mempengaruhi Keputusan Pembelian Pada Toko Fashion Di Jejaring Sosial Facebook (Survei pada Konsumen Toko Fashion di Jejaring Sosial Facebook yang berlokasi di Indonesia). Jurnal Administrasi Bisnis, (online) 10(1),

$1-10$. (http://administrasibisnis.studentjournal.ub.ac.id/in dex.php/jab/ diakses 28 Februari 2019)

Zuelseptia, Sonya., Rahmiati, Rahmiati., dan Engriani, Yunita. 2018. The Influence of Perceived Risk and Perceived Ease of Use on Consumerrs Attitude and Online Purchase Intention. (online) 57(Piceeba), 384-390. (https://doi.org/10.2991/piceeba18.2018.70/ diakses 1 maret 2020) 